\title{
The effect of shoot training on yield, fruit quality and leaf chemical composition of eggplant in greenhouse cultivation
}

\author{
Anna Magdalena Ambroszczyk, Stanisław Cebula, Agnieszka Sękara \\ Department of Vegetable Crops \\ University of Agriculture in Kraków \\ 29 Listopada 54, 31-425 Kraków, Poland \\ e-mail: asekara@ogr.ar.krakow.pl
}

Key words: aubergine, plant pruning, PAR, yielding

\begin{abstract}
The aim of the investigations was to determine the best method of eggplant (Solanum melongena L.) pruning in greenhouse production. The investigations were carried out in $1999-2001$ in the experimental greenhouse of the University of Agriculture in Krakow, Poland. The 'Tania $\mathrm{F}_{1}$ ' hybrid was used in the early spring-summer production in a heated greenhouse. Plants were pruned to one or two shoots. In the case of two-shoot plants, the second shoot was led out from the first, third, sixth and ninth node. The intense pruning positively affected the PAR conditions in the plant profile. The most effective fruit setting was observed in the intensely pruned plants. The greatest number of fruits was set at the lowest nodes. Pruning affected the total but not marketable yield of fruits. Two-shoot plants with the second shoot led out from the sixth node produced the greatest fruits, both in early and total yield. A high level of reducing sugar was found in the fruits of
\end{abstract}


moderately pruned plants. Fruits of two-shoot plants with the second shoot led out from the sixth node and pruned to one shoot contained the greatest level of L-ascorbic acid. The greatest levels of reducing sugar and starch were found in the leaves of moderately pruned plants, having the best PAR conditions. The method of pruning slightly affected the level of pigments in the eggplant leaves.

\section{INTRODUCTION}

Energy-saving techniques have been introduced in eggplant production in the greenhouse to reduce its costs and to increase its efficiency. Among modern techniques, the most promising are grafting (Khah 2005), introduction of bumblebees as pollinators (Abak et al. 2000), use of growth regulators (Pessarakli and Dris 2003), use of parthenocarpic eggplant cultivars (Acciarri et al. 2002), optimization of growth conditions in relation to phase of plant development (Kurklu et al. 1998), and plant pruning (Ambroszczyk et al. 2007).

The eggplant is characterized by an intense vegetative growth causing the excessive density of plants. Plant pruning is an essential procedure taken up to reduce the number of shoots, leaves and fruit sets (Cebula 1996). Amiard et al. (2005) emphasized that plants adjust their capacity to carry out photosynthesis in response to the demand for photosynthesis products. This balance between source (mature, photosynthesizing leaves) and sinks (growing, metabolizing, and storing tissues) is continuously adjusted in response to environmental and developmental cues (for example leaf or fruit cutting). Greenhouse experiments in which tomato plants were grown at different levels of fruit removals showed a strong influence of fruit load on assimilate partitioning between vegetative and generative plant parts (Heuvelink 1997). The fruit setting of sweet pepper depended on assimilate supply to the developing reproductive organs, so that leaf area, leaf removal and alteration of competing signs were found to affect flower and fruit development (Aloni et al. 1996). Ambroszczyk et al. (2007) found that the plant shape modified the photosynthetically active radiation (PAR) conditions in the plant profile of eggplant. Pruning strongly affected the effectiveness of fruit setting, especially in plants pruned to two shoots. The method of pruning should be adapted to the growth rate of cultivar, spacing, and growth conditions (Cebula and Ambroszczyk 2000).

The aim of the investigations was to determine the best method of eggplant pruning in greenhouse production on the base of the yield characteristic and chemical composition of leaves and fruits. 


\section{MATERIAL AND METHODS}

The experiments were conducted in $1999-2001$ in a greenhouse of the University of Agriculture in Kraków, Poland. Eggplant hybrid 'Tania $\mathrm{F}_{1}$ ' (Syngenta Seeds) was used. 'Tania $F_{1}$ ' was characterized by medium-strong growth, high yielding, and oval, purple-black fruits. It is particularly suitable for greenhouse cultivation.

Seeds were sown in boxes filled with peat substrate and placed in a controlled environment: temperature $27 \pm 1{ }^{\circ} \mathrm{C}$ and $\mathrm{RH} 80 \%$. After emergence the temperature was maintained at $26 \pm 2{ }^{\circ} \mathrm{C}$ (day) and $21 \pm 1{ }^{\circ} \mathrm{C}$ (night), $\mathrm{RH}$ at $80 \%$, and an artificial light was provided between 3-10 p.m. When the first true leaf was expanding, uniform seedlings were pricked out into plastic pots $\varnothing 10 \mathrm{~cm}$, filled with peat substrate. Uniform transplants with 5-6 leaves were transplanted into plastic containers $(\varnothing 25 \mathrm{~cm})$, filled with peat-based substrate. The containers were placed directly on the soil surface in a spacing of $80 \times 30 \mathrm{~cm}$. The experimental unit was 10 plants on an area of $2.40 \mathrm{~m}^{2}$. Plants were led with strings tied to transversal wires $2.5 \mathrm{~m}$ above ground. The fertilizer application rate was based on typical recommendations for greenhouse eggplant growing. The fertility status of the substrate was determined by a monthly soil analysis. The frequency and duration of fertilization were varied according to the season as well as plant and substrate status. The air temperature in the greenhouse was maintained at $26 \pm 2{ }^{\circ} \mathrm{C}$ during the day and $19 \pm 1{ }^{\circ} \mathrm{C}$ during the night, and $\mathrm{RH}$ at $80 \%$. Dates of main growing practices are shown in Table 1 .

Table 1. Dates of main growing practices for three years of the experiment

\begin{tabular}{lccc}
\hline \multirow{2}{*}{ Specification } & \multicolumn{3}{c}{ Years } \\
\cline { 2 - 4 } & 1999 & 2000 & 2001 \\
\hline Seed sowing & 19.01 & 21.12 .1999 & 03.01 \\
Emergence & 25.01 & 27.12 .1999 & 17.01 \\
Pricking out & 09.02 & 12.01 & 31.01 \\
Transplanting & 16.03 & 23.02 & 06.03 \\
Beginning of flowering & 19.04 & 21.03 & 07.04 \\
First harvest & 01.06 & 31.05 & 31.05 \\
Last harvest & 07.09 & 11.09 & 11.09 \\
\hline
\end{tabular}

\section{Pruning treatments}

The treatments were arranged in a randomized block design in four replications. Plants were pruned to one (E) or two shoots. In the case of two-shoot plants, the 
second shoot was led out from the first (A), third (B), sixth (C) and ninth (D) node. In all experimental units two fruit sets and two leaves were left in each node: one on the main shoot and one on the side shoot.

Photosynthetically active radiation (PAR) was measured between 12 a.m. 1 p.m. on sunny days, using a linear quantum sensor LI-COR above the plants $(100 \%)$, and at three levels of plant profile: the main embranchment, fruiting, and flowering. Measurements were carried out on 5 July and 12 August 1999, 7 July and 21 August 2000, 25 June and 1 August 2001.

The number of flowers and fruit sets were counted. Fruits at harvest maturity were collected once a week. The first four harvests were treated as an early yield. Fruits were sorted into two classes according to the Agricultural Quality Standard UNECE FFV-05: 2000, concerning the marketing and commercial quality control of eggplants (UNECE Standard FFV-05, 2000).

Fruit samples were collected during the full fruiting period. Dry weight was determined using the desiccator method at $95-98^{\circ} \mathrm{C}$. The modified version of LuffSchoorl's method was used to determine the total sugar concentration; vitamin C was determined by the Tillmans method.

Leaf samples in the phase of intense vegetative growth were collected from the main shoot at three levels of plant profile: the main embranchment, fruiting, and flowering. Dry matter was determined using the desiccator method at $95-98^{\circ} \mathrm{C}$. Leaf pigments were determined after extraction with $80 \%$ acetone and measurement of absorbance at $646 \mathrm{~nm}$ (chlorophyll $a$ ), 663 (chlorophyll $b$ ), and $470 \mathrm{~nm}$ (carotenoids). The anthron method was used to determine the reducing sugar and starch concentration.

The results were given as means from the three-year experiment. Treatment effects were statistically evaluated by ANOVA, Student $t$-test, at $p=0.05$.

\section{RESULTS AND DISCUSSION}

Photosynthetically active radiation in the plant profile depended on the pruning method. At the beginning of fruiting the greatest PAR transmittance was observed at the level of flowering (61-78\% of radiation above the plants). The level of fruiting reached $28-43 \%$, and main embranchment $15-28 \%$ of PAR. During full fruiting, 58-65\% of PAR reached the level of flowering, 36-49\% the level of fruiting, and $17-28 \%$ the level of first embranchment (Fig. 1). In the profile of moderately pruned plants (treatments B and C), PAR conditions at the levels of intensive assimilation were the most suitable for plant development. Cebula and Ambroszczyk (2000) and Cebula (2003) reached similar results. Ambroszczyk et al. (2007) proved that the decrease of PAR values was affected by the remaining greater number of leaves and shoots per plant. 
The most intensive fruit setting was observed in plants pruned to two shoots with the second shoot led out from the sixth node - treatment $\mathrm{C}$ (average for all levels of fruiting 29.2\%); the lowest - in two-shoot plants with the second shoot led out from the first node - was treatment A (16.3\%) (Fig. 2). The most even fruit setting during the vegetation season was observed in the plants pruned to two shoots with the second shoot led out from the ninth node (treatment D). With this system of pruning the vegetative and generative plant development was balanced in the highest degree. Fruits were set effectively on the first three nodes $(33.0 \%$ of flowers set fruits, meanly for all treatments). In the case of 7-9 nodes, only $13.6 \%$ of flowers set fruits, probably due to high daily temperatures and a lowered state of health of the plants. Ambroszczyk et al. (2007) also found that the lowest levels of plant profiles were characterized by the greatest effectiveness of fruit setting.

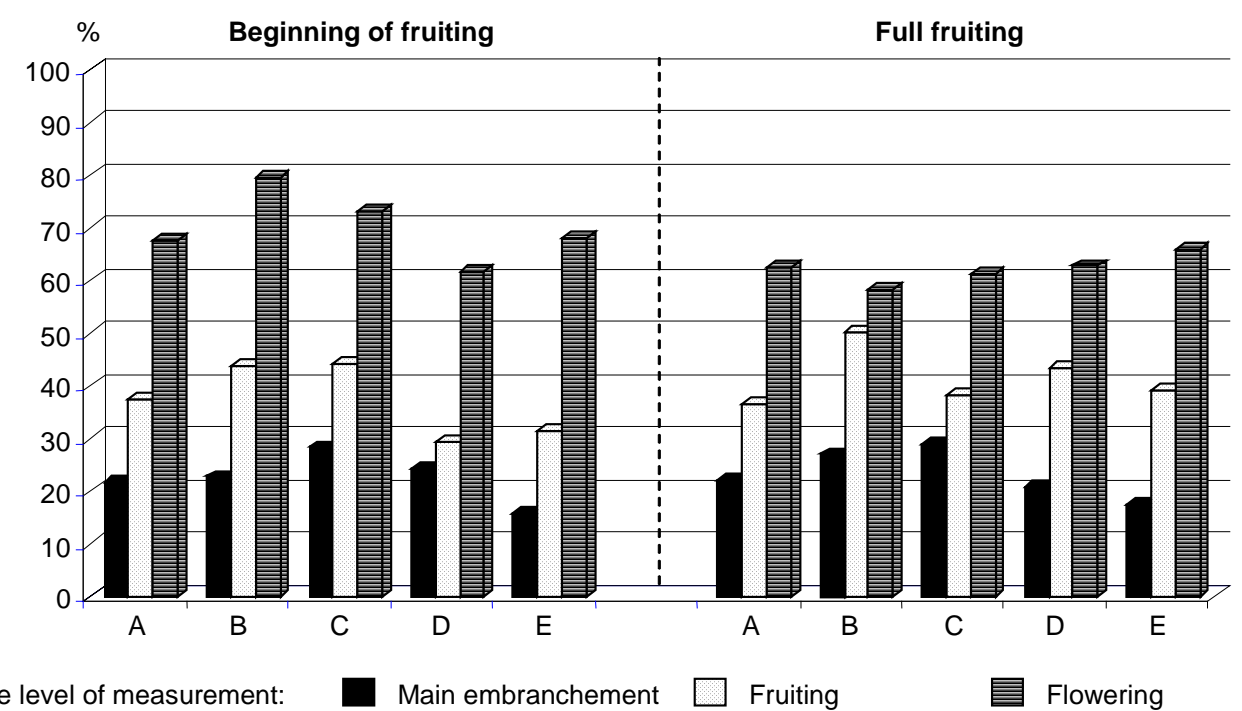

Fig. 1. Photosynthetically active radiation (PAR) as a percentage of irradiation measured above the plants $(100 \%)$.

Explanations: Plants pruned to two shoots with the second shoot led out from the first (A), third (B), sixth (C) and ninth (D) node. Plants pruned to one shoot: E. 


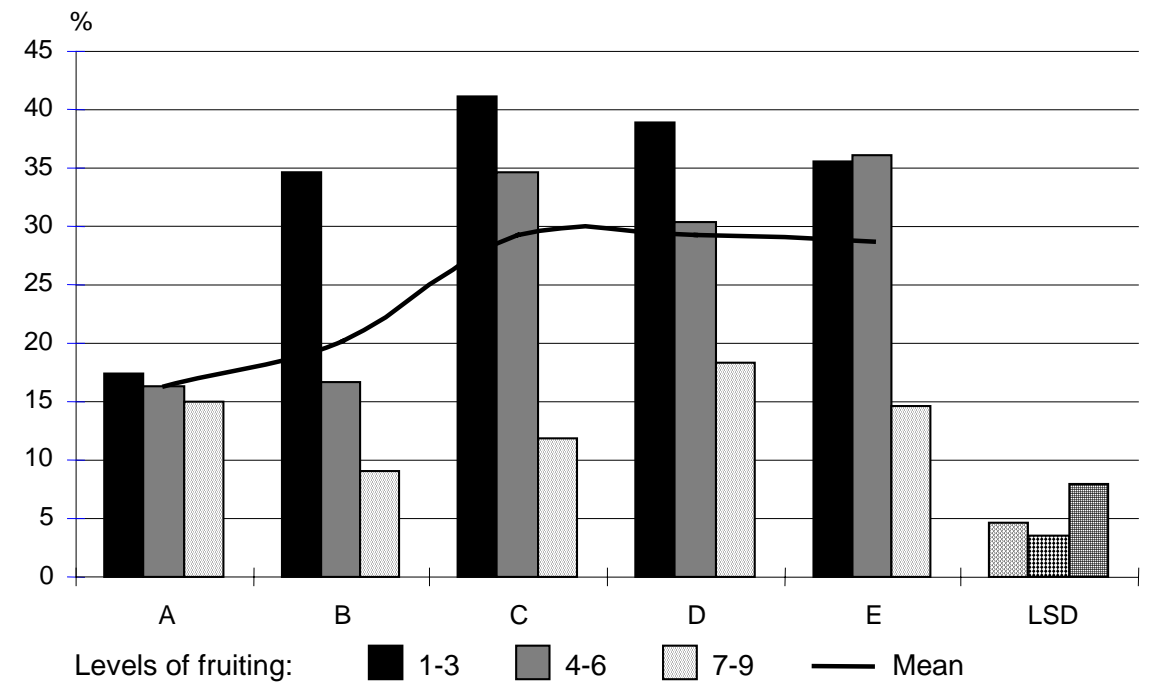

Fig. 2. The percentage of fruit sets depending on pruning method (means for 1999 - 2001). Explanations: see Fig. 1.

Pruning affected the total but not marketable yield of fruits. The early total yield was between $3.25 \mathrm{~kg} \mathrm{~m}^{-2}$ in treatment $\mathrm{E}$ and $4.10 \mathrm{~kg} \mathrm{~m}^{-2}$ in treatment $\mathrm{A}$, and the early marketable yield was between $3.16-3.80 \mathrm{~kg} \mathrm{~m}^{-2}$, in treatments $\mathrm{E}$ and $\mathrm{C}$ respectively (Table 2). The total yield was between $9.90 \mathrm{~kg} \mathrm{~m}^{-2}$ in treatment $\mathrm{B}$ and $11.33 \mathrm{~kg} \mathrm{~m}^{-2}$ in treatment $\mathrm{C}$ (Table 3 ). The number of fruits harvested per square meter was 24.6 to 26.7 in total yield and 19.5-20.8 in marketable yield. Marketable yield was between 8.56 to $9.40 \mathrm{~kg} \mathrm{~m}^{-2}$, without statistical differences between treatments. Carter and Johnson (1988), Düzenk and Abak (1991), Ambroszczyk and Cebula (2000), and Ambroszczyk et al. (2007) stated a wide range of total yield in eggplant $\left(1.45-16.00 \mathrm{~kg} \mathrm{~m}^{-2}\right)$ depending on the cultivar, pruning system, and the growth conditions. Ambroszczyk et al. (2007) stated that the pruning of eggplant did not influence the fruit yield but had a positive effect on the fruit quality. In the present experiment, the greatest fruits were produced by two-shoots plants with the second shoot led out from the sixth node, both in early and total yield (Table 4). The harvested fruits were characterized by a very good quality: $79.4 \%-80.7 \%$ of them were classified as class I (Fig. 3). Also in the experiment conduced by Paksoy and Akilli (1994), the pruning of eggplant to two or three shots resulted in the increase of the number of the best quality fruits. Düzenk and Abak (1991), Passam and Khah (1992), Carter and Johnson (1988), and Ambroszczyk et al. (2007) showed that eggplant produced fruits of mass 138 to $510 \mathrm{~g}$, depending on the cultivar. 
The method of pruning did not affect the dry matter content in the eggplant

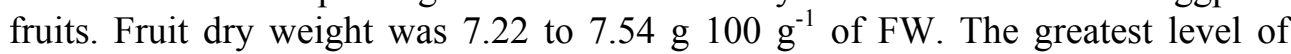
reducing sugar was found in the fruits of moderately pruned plants (treatments $\mathrm{B}, \mathrm{C}$ and D) as opposed to one-shoot plants, which contained the lowest level of reducing sugar in fruits. Fruits of two-shoot plants with the second shoot led out from the sixth node (treatment C) and pruned to one shoot (treatment E) contained the greatest level of L-ascorbic acid (Table 5). The obtained values are comparable with those recorded by Cebula and Ambroszczyk (2000) and Ambroszczyk et al. (2007).

Table 2. Early yield of eggplant (means for $1999-2001$ )

\begin{tabular}{|c|c|c|c|c|}
\hline \multirow{2}{*}{ Experimental trials } & \multicolumn{2}{|c|}{ Total yield } & \multicolumn{2}{|c|}{ Marketable yield } \\
\hline & $\mathrm{kg} \mathrm{m}^{-2}$ & No. $m^{-2}$ & $\mathrm{~kg} \mathrm{~m}^{-2}$ & No. $\mathrm{m}^{-2}$ \\
\hline A & $4.10 \mathrm{a}^{*}$ & $9.7 \mathrm{~b}$ & $3.51 \mathrm{a}$ & $9.2 \mathrm{a}$ \\
\hline B & $3.50 \mathrm{a}$ & $8.6 \mathrm{ab}$ & $3.40 \mathrm{a}$ & $8.3 \mathrm{a}$ \\
\hline $\mathrm{C}$ & $3.85 \mathrm{a}$ & $7.9 \mathrm{a}$ & $3.80 \mathrm{a}$ & $7.8 \mathrm{a}$ \\
\hline $\mathrm{D}$ & $3.76 \mathrm{a}$ & $9.2 \mathrm{ab}$ & $3.86 \mathrm{a}$ & $9.2 \mathrm{a}$ \\
\hline E & $3.25 \mathrm{a}$ & $7.9 \mathrm{a}$ & $3.16 \mathrm{a}$ & $7.8 \mathrm{a}$ \\
\hline
\end{tabular}

* values in columns marked with the same letter do not differ significantly at $\mathrm{p}=0.05$ Explanations: see Fig. 1.

Table 3. Total and marketable yield of eggplant (means for 1999 - 2001)

\begin{tabular}{|c|c|c|c|c|}
\hline \multirow{2}{*}{ Experimental trials } & \multicolumn{2}{|c|}{ Total yield } & \multicolumn{2}{|c|}{ Marketable yield } \\
\hline & $\mathrm{kg} \mathrm{m}^{-2}$ & No. $\mathrm{m}^{-2}$ & $\mathrm{~kg} \mathrm{~m}^{-2}$ & No. $\mathrm{m}^{-2}$ \\
\hline A & $10.20 \mathrm{ab}^{*}$ & $25.5 \mathrm{a}$ & $8.74 \mathrm{a}$ & $20.6 \mathrm{a}$ \\
\hline B & $9.90 \mathrm{a}$ & $24.6 \mathrm{a}$ & 8.56 a & $20.1 \mathrm{a}$ \\
\hline $\mathrm{C}$ & $11.33 \mathrm{~b}$ & $26.7 \mathrm{a}$ & $9.40 \mathrm{a}$ & $19.5 \mathrm{a}$ \\
\hline $\mathrm{D}$ & $10.80 \mathrm{ab}$ & $26.0 \mathrm{a}$ & $9.02 \mathrm{a}$ & $19.6 \mathrm{a}$ \\
\hline $\mathrm{E}$ & $10.40 \mathrm{ab}$ & $24.6 \mathrm{a}$ & $8.82 \mathrm{a}$ & $20.8 \mathrm{a}$ \\
\hline
\end{tabular}

* values in columns marked with the same letter do not differ significantly at $\mathrm{p}=0.05$ Explanations: see Fig. 1. 


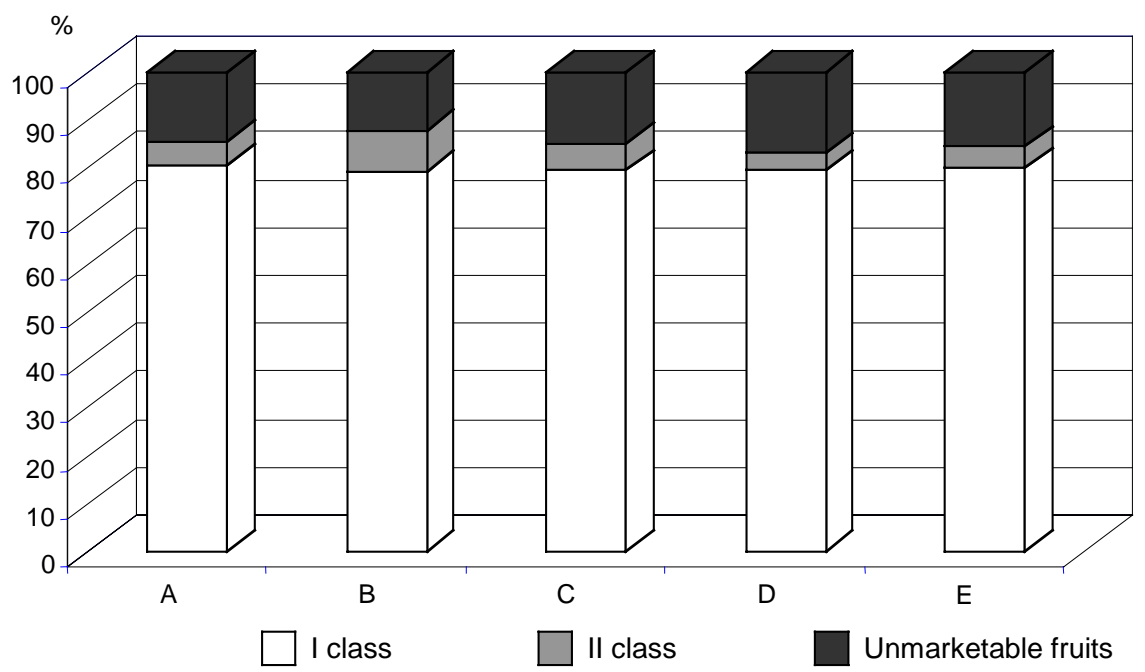

Fig. 3. Structure of the total yield of eggplant depending on the pruning method (means for 1999 2001). Explanations: see Fig. 1.

The level of dry matter in the eggplant leaves differed among the experimental

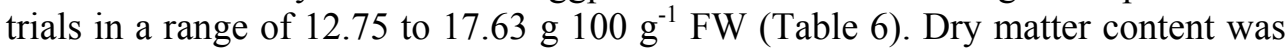
the greatest at the level of flowering, followed by the level of fruiting and main

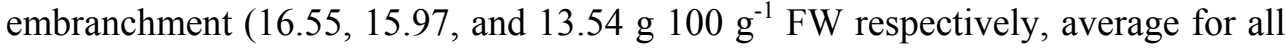
treatments) as the result of the ageing of leaves at the lowest levels. Starch content was greatest in the leaves at the level of fruiting and flowering (17.84 and 18.28 $\mathrm{mg} \mathrm{g}^{-1}$ DW respectively, average for all treatments), and the lowest at the level of main embranchment (15.66 $\mathrm{mg} \mathrm{g}^{-1} \mathrm{DW}$, average for all treatments). The content of reducing sugar in the eggplant leaves was similar to the starch content: the greatest at the level of fruiting (29.01 $\mathrm{mg} \mathrm{g}^{-1} \mathrm{DW}$, on average for all treatments), followed by the level of flowering and the main embranchment $\left(28.06\right.$ and $25.80 \mathrm{mg} \mathrm{g}^{-1} \mathrm{DW}$ respectively, average for all treatments). The greatest level of reducing sugar and starch was found in the leaves of moderately pruned plants (treatments B and C), characterized by the best PAR conditions in the plant profile. One-shoot plants contained the lowest level of starch in leaves $\left(14.41 \mathrm{mg} \mathrm{g}^{-1} \mathrm{DW}\right.$, mean for all levels). The lowest content of reducing sugar was found in the leaves of plants pruned to two shoots (23.78 $\mathrm{mg} \mathrm{g}^{-1} \mathrm{DW}$, mean for all levels), as a result of poorer light conditions, lower rate of photosynthesis and lower productivity. Murage et al. (1996 and 1997) found significantly lower content of starch in eggplant leaves in comparison to present results. 
The youngest leaves from the level of flowering contained the greatest amount of chlorophyll $a, b$ and carotenoids, i.e. on average $1.60,0.59$ and $0.52 \mathrm{mg} \mathrm{g}^{-1} \mathrm{FW}$, respectively; as opposed to the oldest leaves from the level of main embranchment, i.e. on average $1.15,0.48$ and $0.42 \mathrm{mg} \mathrm{g}^{-1} \mathrm{FW}$, respectively (Table 7). The method of pruning slightly affected the level of pigments in the eggplant leaves. Murage et al. (1996, 1997) and Park et al. (1996) determined the chlorophyll $a$ content in the eggplant leaves in the range of $0.26-1.27 \mathrm{mg} \mathrm{g}^{-1} \mathrm{FW}$, chlorophyll $b \quad 0.11$ $0.37 \mathrm{mg} \mathrm{g}^{-1} \mathrm{FW}$, and the sum of chlorophylls $0.07-1.40 \mathrm{mg} \mathrm{g}^{-1} \mathrm{FW}$.

Table 4. Mean fruit weight (g) of eggplant depending on the pruning method (means for 1999 - 2001)

\begin{tabular}{ccccc}
\hline Experimental trials & $\begin{array}{c}\text { Early total } \\
\text { yield }\end{array}$ & $\begin{array}{c}\text { Early marketable } \\
\text { yield }\end{array}$ & $\begin{array}{c}\text { Total } \\
\text { yield }\end{array}$ & Marketable yield \\
\hline A & $411.4 \mathrm{a}^{*}$ & $405.1 \mathrm{a}$ & $400.0 \mathrm{a}$ & $405.1 \mathrm{a}$ \\
$\mathrm{B}$ & $407.0 \mathrm{a}$ & $409.6 \mathrm{a}$ & $402.4 \mathrm{a}$ & $425.9 \mathrm{a}$ \\
C & $487.3 \mathrm{~b}$ & $487.2 \mathrm{a}$ & $424.3 \mathrm{~b}$ & $482.1 \mathrm{~b}$ \\
D & $408.7 \mathrm{a}$ & $419.6 \mathrm{a}$ & $415.4 \mathrm{ab}$ & $460.2 \mathrm{ab}$ \\
E & $422.7 \mathrm{ab}$ & $382.0 \mathrm{a}$ & $422.7 \mathrm{ab}$ & $424.0 \mathrm{a}$ \\
\hline
\end{tabular}

*values in columns marked with the same letter do not differ significantly at $\mathrm{p}=0.05$

Explanations: see Fig. 1.

Table 5. The content of dry matter, reducing sugar and L-ascorbic acid in the eggplant fruits depending on the pruning method (means for 1999 - 2001)

\begin{tabular}{|c|c|c|c|}
\hline Experimental trials & $\begin{array}{c}\text { Dry matter } \\
\left.\text { (g } 100 \mathrm{~g}^{-1} \mathrm{FW}\right)\end{array}$ & $\begin{array}{l}\text { Reducing sugar } \\
\left(\mathrm{mg} \mathrm{g}^{-1} \mathrm{DW}\right)\end{array}$ & $\begin{array}{l}\text { L-ascorbic acid } \\
\left(\mathrm{mg} 100 \mathrm{~g}^{-1} \mathrm{FW}\right)\end{array}$ \\
\hline A & $7.54 \mathrm{a}^{*}$ & $2.74 \mathrm{ab}$ & $6.47 \mathrm{ab}$ \\
\hline $\mathrm{B}$ & $7.22 \mathrm{a}$ & $2.90 \mathrm{bc}$ & $6.37 \mathrm{ab}$ \\
\hline $\mathrm{C}$ & $7.22 \mathrm{a}$ & $2.90 \mathrm{bc}$ & $6.55 \mathrm{~b}$ \\
\hline $\mathrm{D}$ & $7.27 \mathrm{a}$ & $2.92 \mathrm{c}$ & $6.10 \mathrm{a}$ \\
\hline $\mathrm{E}$ & $7.51 \mathrm{a}$ & $2.70 \quad \mathrm{a}$ & $6.55 \mathrm{~b}$ \\
\hline
\end{tabular}

*values in columns marked with the same letter do not differ significantly at $\mathrm{p}=0.05$

Explanations: see Fig. 1. 
Table 6. The content of dry matter, starch and reducing sugar in the eggplant leaves depending on the pruning method (means for 1999 - 2001)

\begin{tabular}{|c|c|c|c|c|}
\hline $\begin{array}{l}\text { Experimental } \\
\text { trials }\end{array}$ & $\begin{array}{c}\text { The level of } \\
\text { measurement }\end{array}$ & $\begin{array}{c}\text { Dry matter } \\
\left({\left.\mathrm{g} 100 \mathrm{~g}^{-1} \mathrm{FW}\right)}\right.\end{array}$ & $\begin{array}{c}\text { Starch } \\
\left(\mathrm{mg} \mathrm{g}^{-1} \mathrm{DW}\right)\end{array}$ & $\begin{array}{l}\text { Reducing sugar } \\
\left(\mathrm{mg} \mathrm{g}^{-1} \mathrm{DW}\right)\end{array}$ \\
\hline \multirow{3}{*}{ A } & $\mathrm{I}^{* *}$ & $14.03 \mathrm{~b}^{*}$ & $13.65 \mathrm{a}$ & 27.30 cde \\
\hline & II & 17.03 ef & $13.52 \mathrm{a}$ & $23.10 \mathrm{ab}$ \\
\hline & III & $15.85 \mathrm{~cd}$ & $17.30 \mathrm{~d}$ & $20.95 \mathrm{a}$ \\
\hline \multirow{3}{*}{ B } & $\mathrm{I}$ & $12.75 \mathrm{a}$ & $17.00 \mathrm{~cd}$ & 29.90 ef \\
\hline & II & $15.18 \mathrm{bc}$ & $20.80 \mathrm{e}$ & $28.93 \mathrm{def}$ \\
\hline & III & 17.25 ef & $20.23 \mathrm{e}$ & $25.78 \mathrm{~cd}$ \\
\hline \multirow{3}{*}{$\mathrm{C}$} & I & $14.05 \mathrm{~b}$ & $20.60 \mathrm{e}$ & $32.80 \mathrm{fg}$ \\
\hline & II & $15.68 \mathrm{~cd}$ & $23.65 \mathrm{f}$ & 30.63 efg \\
\hline & III & $15.78 \mathrm{~cd}$ & $21.83 \mathrm{bcd}$ & 30.06 efg \\
\hline \multirow{3}{*}{$\mathrm{D}$} & I & $12.77 \mathrm{a}$ & $13.80 \mathrm{ab}$ & $24.00 \mathrm{abc}$ \\
\hline & II & $16.58 \mathrm{def}$ & $16.88 \mathrm{~cd}$ & 34.00 \\
\hline & III & $17.63 \mathrm{f}$ & $16.40 \mathrm{bcd}$ & $25.50 \mathrm{bcd}$ \\
\hline \multirow{3}{*}{$\mathrm{E}$} & I & $14.08 \mathrm{~b}$ & $13.23 \mathrm{a}$ & 27.20 cde \\
\hline & II & 15.40 & $14.35 \mathrm{abc}$ & $28.38 \mathrm{de}$ \\
\hline & III & 16.22 cde & $15.65 \mathrm{abcd}$ & 26.73 bcde \\
\hline
\end{tabular}

*values in columns marked with the same letter do not differ significantly at $p=0.05$

**I - main embranchment, II - fruiting, III - flowering

Explanations: see Fig. 1.

Table 7. The content of pigments ( $\mathrm{mg} \mathrm{g}^{-1} \mathrm{FW}$ ) in the eggplant leaves depending on the pruning method (means for $1999-2001$ )

\begin{tabular}{|c|c|c|c|c|c|}
\hline $\begin{array}{l}\text { Experimental } \\
\text { trials }\end{array}$ & $\begin{array}{l}\text { The level of } \\
\text { measurement }\end{array}$ & $\begin{array}{c}\text { Chlorophyll } \\
a\end{array}$ & $\begin{array}{c}\text { Chlorophyll } \\
b \\
\end{array}$ & $\begin{array}{l}\text { The sum of } \\
\text { chlorophylls }\end{array}$ & Carotenoids \\
\hline \multirow{3}{*}{ A } & $\mathrm{I}$ & $1.20 \mathrm{bc}^{*}$ & $0.48 \quad a b$ & $1.68 \mathrm{abc}$ & $0.41 \mathrm{ab}$ \\
\hline & II & $1.39 \mathrm{e}$ & $0.56 \mathrm{de}$ & $1.95 \mathrm{~cd}$ & $0.47 \mathrm{~cd}$ \\
\hline & III & $1.66 \mathrm{~h}$ & $0.63 \mathrm{~g}$ & $2.29 \mathrm{e}$ & $0.53 \mathrm{e}$ \\
\hline \multirow{3}{*}{ B } & $\mathrm{I}$ & $1.04 \mathrm{a}$ & $0.45 \quad \mathrm{a}$ & 1.49 & $0.38 \quad \mathrm{a}$ \\
\hline & II & $1.28 \mathrm{cde}$ & $0.52 \mathrm{bcd}$ & 1.80 & $0.48 \mathrm{~cd}$ \\
\hline & III & $1.52 \mathrm{fg}$ & 0.59 efg & $2.11 \mathrm{de}$ & $0.53 \mathrm{e}$ \\
\hline \multirow{3}{*}{$\mathrm{C}$} & $\mathrm{I}$ & $1.10 \mathrm{ab}$ & $0.46 \mathrm{ab}$ & $1.56 \mathrm{ab}$ & $0.42 \mathrm{ab}$ \\
\hline & II & $1.22 \mathrm{~cd}$ & $0.51 \mathrm{~cd}$ & $1.73 \mathrm{abc}$ & $0.44 \mathrm{bc}$ \\
\hline & III & 1.58 & $0.62 \mathrm{fg}$ & 2.20 & $0.51 \mathrm{de}$ \\
\hline \multirow{3}{*}{$\mathrm{D}$} & $\mathrm{I}$ & $1.17 \mathrm{bc}$ & $0.51 \mathrm{~cd}$ & $1.68 \mathrm{abc}$ & $0.42 \mathrm{ab}$ \\
\hline & II & 1.40 ef & $0.46 \mathrm{ab}$ & $1.86 \mathrm{~cd}$ & $0.53 \mathrm{e}$ \\
\hline & III & $1.68 \mathrm{~h}$ & $0.51 \mathrm{~cd}$ & 2.19 & $0.53 \mathrm{e}$ \\
\hline \multirow{3}{*}{ E } & $\mathrm{I}$ & $1.24 \mathrm{~cd}$ & $0.50 \quad a b c$ & 1.74 & $0.45 \mathrm{bc}$ \\
\hline & II & $1.33 \mathrm{de}$ & $0.57 \mathrm{def}$ & 1.90 & $0.48 \mathrm{~cd}$ \\
\hline & III & $1.57 \mathrm{gh}$ & 0.61 efg & 2.18 & 0.52 de \\
\hline
\end{tabular}

*values in columns marked with the same letter do not differ significantly at $p=0.05$

** I - main embranchment, II - fruiting, III - flowering

Explanations: see Fig. 1. 


\section{CONCLUSIONS}

1. The intense pruning positively affected the PAR conditions in the plant profile.

2. The most effective fruit setting was observed in the intensively pruned plants. The greatest number of fruits was set at the lowest nodes.

3. Pruning affected the total but not marketable yield of fruits. The greatest fruits were produced by two-shoots plants with the second shoot led out from the sixth node, both in early and total yield.

4. The greatest level of reducing sugar was found in the fruits of moderately pruned plants. Fruits of two-shoot plants with the second shoot led out from the sixth node and pruned to one shoot contained the greatest level of L-ascorbic acid.

5. The greatest level of reducing sugar and starch was found in the leaves of moderately pruned plants, characterized by the best PAR conditions. Method of pruning slightly affected the level of pigments in the eggplant leaves.

\section{REFERENCES}

Abak K., Özdogan A.O., Dasgan H.Y., Derin K., Kaftanoglu O., 2000. Effectiveness of bumble bees as pollinators for eggplants grown in unheated greenhouses. Acta Hort. (ISHS) 514: 197-204, http://www.actahort.org/books /514/514_22.htm.

Acciarri N., Restaino F., Vitelli G., Perrone D., Zottini M., PANDolfini T., SPENA A., RoTINO G.L., 2002. Genetically modified parthenocarpic eggplants: improved fruit productivity under both greenhouse and open field cultivation. Biotechnol. 2: http://www.biomedcentral.com/1472-6750/2/4.

Aloni B., KARni L., Zaidman Z., SCHAFFer A.A., 1996. Changes of carbohydrates in pepper (Capsicum annuum L.) flowers in relation to their abscission under different shading regimes. Ann. Bot. 78: 163-168.

AmbroszczyK A., CeBUla S., 2000. Wpływ defoliacji roślin na wzrost, plonowanie i jakość owoców oberżyny w uprawie szklarniowej. Roczn. AR Poznań 323(2): 209-213.

AmbroszczyK A.M., Cebula S., SęKARA A., 2007. The effect of plant pruning on yield and fruit quality of eggplant (Solanum melongena L.) in greenhouse cultivation. Hort. Environ. Biotechnol. 48, 5: 277-285. 
Amiard V., Mueh K.E., Demmig-Adams B., Ebbert V., Turgeon R., Adams W.W., 2005. Anatomical and photosynthetic acclimation to the light environment in species with different mechanisms of phloem loading. PNAS 102(36): 12968-12973.

CARTER J., JOHNSON C., 1988. Influence of different types of mulches on eggplant production. HortSci. 23(1): 143-145.

CeBula S., 1996. Wpływ cięcia roślin na wzrost, plonowanie i jakość owoców 2 odmian oberżyny (Solanum melongena L.) w uprawie szklarniowej. Acta Agr. Silv. ser Agr. 34: 1-11.

Cebula S., AmbroszczyK A., 2000. Wpływ defoliacji roślin na wzrost, plonowanie i jakość owoców oberżyny w uprawie szklarniowej. Roczn. AR Poznań 323(2): 233-237.

CEBULA S., 2003. The effect of side shoots pruning on the growth and yielding of eggplant (Solanum melongena L.) in greenhouse production. Folia Hort. 15/2:71-76.

DÜZENK S., ABAK K., 1991. Alcak tünel ve malc uygulamalarinin biberde stoma yogunluĝu üzerine etkisi. J. Agric. Fac. Ç. Ü. 8(1): 101-108.

HEUVELINK E., 1997. Effect of fruit load on dry matter partitioning in tomato. Sci. Hort. 69: 51-59.

KHAH E.M., 2005. Effect of grafting on growth, performance and yield of aubergine (Solanum melongena L) in the field and greenhouse. J. Food Agric. Environ. 3(34): 92-94 .

KuRKLU A., HAdLEY P., WHELDON A., 1998. Effects of temperature and time of harvest on the growth and yield of aubergine (Solanum melongena L.). Tr. J. Agric. For. 22: 341-348.

MURAGE E.N., WATASHIRO N., MASUDA M., 1996. Leaf chlorosis and carbon metabolism of eggplant in response to continous light and dioxycarbon. Sci. Hort. 67: 27-37.

Murage E.N., WATAShiro N., Masuda M., 1997. Influence of light quality, PPFD and temperature on leaf chlorosis of eggplants grown under continous ilumination. Sci. Hort. 68: 73-82.

PAKSOY M., AKILli M., 1994. The effects of different prunings on the yield and quality of eggplant cultivars grown in the greenhouse conditions. Acta Hort. 366: 287-292.

PARK J.M., Ro H.M., KIM Y.M., SEONGH C., 1996. Chlorophyll determination in horticultural crops using dimethyl sulphoxide. ROA J. Agri. Sci. 38(1): 553-557. 
PASSAM H.C., KHAH E.M., 1992. Flowering, fruit set and fruit and seed development in two cultivars of aubergine (Solanum melongena L.) grown under plastic cover. Sci. Hort. 51: 179-185.

PESSARAKLI M.M., DRIS R., 2003. Effects of pruning and spacing on the yield and quality of eggplant. Food Agric. Environ. 1(2): 215-216.

UNECE STANDARD FFV-05, 2000. United Nations Economic Commission for Europe. Working Party on Agricultural Quality Standards. Fresh Fruits and Vegetables. www.unece.org.

\section{WPŁYW SPOSOBU WYPROWADZENIA PECÓW PRZEWODNICH NA PLON, JAKOŚĆ OWOCÓW I SKŁAD CHEMICZNY LIŚCI OBERŻYNY W UPRAWIE SZKLARNIOWEJ}

Streszczenie: Celem badań było opracowanie najlepszej metody cięcia oberżyny (Solanum melongena L.). Badania prowadzono w latach 1999 - $2001 \mathrm{w}$ szklarni doświadczalnej Akademii Rolniczej w Krakowie. Przedmiotem badań była odmiana 'Tania $F_{1}$ '. Rośliny były prowadzone jednopędowo lub dwupędowo, przy czym drugi pęd wyprowadzano z pierwszego, trzeciego, szóstego lub dziewiątego węzła. Cięcie poprawiło warunki PAR w profilu roślin. Najefektywniejsze wiązanie owoców zaobserwowano u intensywnie ciętych roślin, przy czym najwięcej owoców zawiązała oberżyna w najniższych węzłach. Cięcie wpłynęło na plon ogółem, ale nie wpłynęło na plon handlowy owoców. Największe owoce zebrano z roślin, u których drugi pęd wyprowadzano z szóstego węzła. Największą zawartość cukrów redukujących stwierdzono w owocach zebranych $\mathrm{z}$ umiarkowanie ciętych roślin. Najwięcej kwasu L-askorbinowego stwierdzono w owocach roślin jednopędowych oraz $\mathrm{z}$ drugim pędem wyprowadzanym z szóstego węzła. Najwięcej cukrów redukujących i skrobi zawierały liście umiarkowanie ciętych roślin, które cechowały najlepsze warunki PAR. 